\title{
Indeksikalitas Makanan Tradisional dalam Upacara Pawiwahan Masyarakat Desa Tibuneneng
}

\author{
Ni Nyoman Widani ${ }^{1)}$, Nelsye Lumanauw ${ }^{2)}$, Wiya Suktiningsih ${ }^{3)}$ \\ ${ }^{1}$ Politeknik Internasional Bali \\ wiwinwidani1968@gmail.com \\ ${ }^{2}$ Politeknik Internasional Bali \\ nelsyelumanauw@gmail.com \\ ${ }^{3}$ Universitas Bumigora \\ wiya.suktiningsih@universitasbumigora.ac.id
}

Received: $19^{\text {th }}$ September 2021| Revised: $26^{\text {th }}$ October 2021| Accepted: $2^{\text {nd }}$ December 2021

Email Correspondence: wiya.suktiningsih@universitasbumigora.ac.id

\begin{abstract}
Traditional ceremonies are part of the culture and traditions of the Tibubeneng village community and are also related to the activities of the Hinduism. In the implementation of customs there are rules and prerequisites that must exist, one of which is traditional food. This study aims to find out the function and existence of a food in the traditional ceremony of the Tibubeneng tourism village community. The research method used in this research is descriptive qualitative research method. The ethnographic method is used by researchers to analyze the function and meaning of traditional foods used in traditional ceremonies, judging from the current form of performance whether there is a difference with a requirement in the rules of a traditional ceremony. To analyze activities, activities, meaning of traditional food used in traditional ceremonies, researchers will conduct in-depth interviews with the Bendesa adat, Pemangku adat and Stakeholders. There are 8 types of food that must be present in the Pawiwahan event, namely: Sambal embe, satay, lawar, Jukut, tum, urab, be'urutan, betutu. Every food that must be served as the main staple food in the Pawiwahan ceremony has meaning and is believed to be a category. prayer for the bride and groom when entering domestic life. These foods are also categorized as sacred/holy foods, because they are used as offerings/bantens in religious ceremonies or customs of the Balinese ethnic community. Along with the rate of population growth in Tibubeneng Village, many immigrants from various ethnicities and religions settled in Tibubeneng village, influencing the original culinary culture of the Tibubeneng village community. However, the strong application of awig-awig by the surrounding community is able to maintain the indexicality of traditional foods that must be present in the Pawiwahan ceremony.
\end{abstract}

Keywords: Pawiwahan ceremony, Tibubeneng village community, traditional food, meaning

\begin{abstract}
Abstrak
Upacara adat sebagai salah satu bagian dari budaya dan tradisi kehidupan masyarakat desa Tibubeneng dan juga berhubungan dengan kegiatan masyarakatnya yang mayoritas memeluk agama Hindu. Dalam pelaksanaan upacara adat terdapat aturan dan prasayarat yang wajib ada, salah satunya adalah makanan tradisional. Penelitian ini bertujuan untuk mencari fungsi dan makna keberadaan suatu makanan dalam upacara adat masyarakat desa wisata Tibubeneng. Metode penelitian yang digunakan dalam penelitian ini adalah metode penelitian kualitatif deskriptif. Metode etnografi digunakan peneliti untuk menganalisi fungsi dan makna dari makanan tradisional yang digunakan dalam upacara adat, dilihat dari bentuk perfomasinya saat ini apakah ada perbedaan dengan keharusan dalam aturan suatu upacara adat. Untuk menganalisa aktivitas, penafsiran, pemaknaan akan makanan tradisonal yang digunakan pada upacara adat, peneliti akan melakukan deep interview dengan
\end{abstract}

Online at https://journal.universitasbumigora.ac.id/index.php/humanitatis/

DOI : https://doi.org/10.30812/humanitatis.v8i1.1465 
Bendesa Adat dan Pemangku. Jenis makanan yang wajib ada dalam acara pawiwahan ada 8 jenis yaitu : Sambal embe, sate, lawar, Jukut, tum, urab, be'urutan, betutu. Setiap makanan yang yang wajib disajikan sebagai makanan pokok utama dalam upacara Pawiwahan memiliki makna dan dipercayai sebagai pengharapan/doa bagi pasangan pengantin kerika memasuki kehidupan rumah tangga. Makanan tersebut juga dikategorikan sebagai makanan sukla/suci, dikarenakan dijadikan bahan persembahan/banten dalam upacara keagamaan ataupun adat istiadat masyarakat etnis Bali. Seiring dengan laju pertumbuhan penduduk di Desa Tibubeneng, banyak pendatang dari berbagai etnis dan agama yang menetap di desa Tibubeneng, mempengaruhi budaya kuliner asli masyarakat desa Tibubeneng. Namun kuatnya penerapan awig-awig oleh masyarakat sekitar mampu mempertahankan indeksikalitas makanan tradisional yang wajib ada dalam upacara Pawiwahan.

Kata kunci: upacara pawiwahan, masyarakat desa tibubeneng, makanan tradisional, makna

\section{PENDAhUluAN}

Indonesia selain terkenal sebagai negara yang memiliki banyak suku, bahasa, agama dan budaya, juga terkenal sebagai negara yang kaya akan keanekaragaman rempah dan hasil bumi seperti padi, ketan, jagung, sagu dan lainnya. Masyarakat Indonesia mengolah rempah dan hasil bumi menjadi suatu makanan tradisional yang memiliki cita rasa yang khas. Makanan tradisonal adalah makanan yang sudah membudaya dari generasi ke generasi. Bahan alam yang tersedia diolah dengan berbagai teknik dan mempunyai fungsi khusus baik sebagai makanan ritual maupun sebagai makanan sehari-hari. Berkaitan dengan fungsi variasi makanan dengan jenis yang cukup banyak, disertai proses pembuatan atau pengolahannya yang masih secara tradisional(Tyas, 2017). Tampilan makanan tradisional terlihat sederhana tetapi proses pembuatannya sangatlah sulit dilakukan. Hal tersebut menjadikan antusias masyarakat untuk menekuni atau membuat makanan tradisional menurun dan lebih tertarik untuk membuat makanan modern yang pembuatannya lebih mudah dan memakan waktu yang lebih singkat. Seiring dengan kemajuan jaman, keberadaan makanan tradisional saat ini mulai tergantikan dengan makanan modern. Saat ini pengetahuan tentang proses pembuatan dan makna makanan tradisional hanya diketahui oleh para orang tua, sedangkan generasi muda saat ini kurang tertarik dengan makanan tradisional. Di Bali pelaku pembuat makanan tradisional ini masih banyak bertahan karena besarnya kebutuhan masyarakat Bali menggunakan makanan tradisional sebagai persembahan/ sukla dalam upacara adat khususnya bagi masyarakat Desa Tibubeneng. Pada upacara adat makanan tradisional yang disajikan sebagai persembahan memiliki fungsi dan makna yang terkandung, berdasarkan presfektif budaya masyarakat Desa Tibubeneng. Setiap upacara adat memiliki varian makanan tradisional yang berbeda-beda sesuai upacara adat yang dilakukan. Upacara adat memiliki hubungan dengan kegiatan keagamaan masyarakat desa Tibubeneng yang mayoritas beragama Hindu. Koentjaraningrat (1980:140) menjelaskan bahwa upacara adat merupakan serangkaian kegiatan yang dilakukan secara bersama oleh masyarakat dalam suatu komunitas sebagai bentuk kebangkitan dalam diri masyarakat(Taya, Rumampuk, \& Sandiah, 2021). Upacara adat dilakukan pada setiap tahapan siklus daur hidup sebagai seorang manusia, dimulai dari 
lahir, beranjak dewasa, pernikahan, melahirkan hingga kematian. Menurut Thomas Wiyasa Bratawidjaya (2006) dijelaskan bahwa upacara adat merupakan serangkaian kegiatan yang bersifat tradisional yang dilakukan secara turun temurun yang memiliki makna dan tujuan di dalamnya(Kartika, 2020).

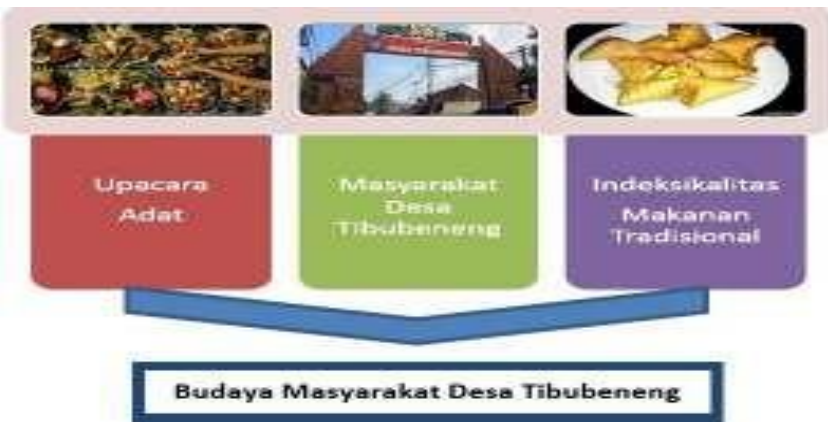

Gambar 1. Indikator Penelitian

Upacara pawiwahan adalah salah satu upacara adat yang bermakna sebagai tahapan legitimasi terhadap adanya niat sepasang kekasih untuk membangun rumah tangga bersama dalam tradisi masyarakat Hindu di Bali yang dilaksanakan berdasarkan kesepakatan kedua belah pihak keluarga (Pawana, 2018). Upacara pawiwahan memiliki keanekaragaman tradisi berdasarkan awig-awig yang berlaku pada suatu masyarakat. Perbedaan dapat diketahui dari rangkaian acara, banten yang digunakan dan aturan-aturan yang berlaku di pihak mempelai. Menurut kepercayaan umat Hindu seperti yang tertulis pada kitab Manusmrti, Wiwaha Samskara (upacara perkawinan) atau disebut juga dengan pawiwahan adalah ikatan suci dan komitmen seumur hidup menjadi suami-istri dan merupakan ikatan sosial yang paling kuat antara laki laki dan perempuan, yang dikaitkan sebagi manusia yadnya, mereka memiliki tujuan untuk mendapatkan keturunan dan menebus dosa para orang tua dengan menurunkan seorang putra yang suputra sehingga akan tercipta keluarga yang bahagia di dunia/jagadhita dan kebahagiaan kekal/moksa(Ningsih \& Suwendra, 2020). Rumusan yang diangkat dalam penelitian ini adalah indesikalitas makanan tradisional yang digunakan dalam upacara adat pawiwahan masyarakat desa Tibubeneng dan bentuk lingual alat, bahan dan aktivitas dalam proses pembuatan makanan tradisional tersebut.

\section{METODE PENELITIAN}

Rancangan penelitian ini adalah penelitian deskriptif kualitatif yang mengolah data data deskriptif yang berupa data tertulis dan data lisan yang di dapatkan dari hasil pengamatan dari subyek penelitian. Penelitian di lakukan di pada desa adat yang ada diwilayah desa Tibubeneng,yaitu Desa Adat Padonan, Desa Adat Tandeg, dan Desa Adat Berawe. Pada tahapan penyediaan data, peneliti menggunakan metode etnografi. Dimana peneliti harus terjun langsung terlibat dalam pelaksanaan upacara adat khususnya pada upacara adat Pawiwahan. Peneliti menginventarisir data makanan 
tradisional yang keberadaannya wajib dalam upacara adat tersebut, selain itu juga peneliti melakukan deep interview kepada para informan untuk memvalidasi data yang sudah terinventarisir dan menggali makna dari makanan tradisional berdasarkan presfektif budaya masyarakat desa Tibubeneng. Informan yang dijadikan narasumber dalam penelitian ini berdasarkan kelompok umur 40 - 70 tahun, memiliki pengetahuan tentang adat Bali, memiliki status sebagai tokoh masyarakat, Bendesa Adat, Jero mangku dan istri pemangku dalem. Analisis data dilakukan dengan mengklarifikasi, mengelompokan data berdasarkan apa yang menjadi tujuan penelitian itu.

\section{PEMBAHASAN}

Upacara Pawiwahan masyarakat desa Tibubeneng berdasarkan tradisi yang berlaku, dilakukan beberapa tahap mulai dari persiapan, proses pelaksanaan dan pacsa pelaksanaan. Setiap tahapan proses pelaksanaan memiliki symbol dan makna yang bertujuan sebagai pengharapan kepada kedua mempelai yang akan mulai melanjutkan tahapan kehidupan dalam suatu rumah tangga. Pada tahapan persiapan masyarakat desa Tibubeneng menentukan hari baik sesuai dengan perhitungan dalam kalender Bali. Berdasarkan kepercayaan masyarakat setempat pemilihan hari baik sangat penting dilakukan, karena sukses tidaknya ritual yang dilakukan serta akibat yang ditimbulkan terhadap perkawinan ke depannya ditentukan oleh pilihan hari tersebut. Berdasarkan tradisi masyarakat Tibubeneng rangkaian prosesi upacara Pawiwahan ada 4 tahapan yaitu :

1. Menentukan hari Baik atau Nyedek, pada tahapan ini kedua keluarga calon mempelai menentukan hari baik untuk setiap tahapan prosesi yang ada pada upacara Pawiwahan. Pada tahapan ini orang tua keluarga calon mempelai laki-laki datang kerumah wanita untuk memberitahukan bahwa di waktu yang telah ditentukan, perwakilan keluarga terdekat laki-laki akan mendatangi rumah keluarga calon mempelai wanita untuk mererawosan tentang keberlanjutan hubungan anak dari kedua keluarga.

2. Dharma Swaka/Gama Swaka atau disebut juga dengan ngidih adalah prosesi meminang calon mempelai wanita. Sesuai kesepakatan keluarga calon mempelai pria mendatangi rumah calon mempelai wanita, dengan menyertakan sejumlah kerabat yang dituakan, untuk membicarakan kesungguhan kedua calon mempelai. Dalam prosesi ini kedua belah pihak keluarga mengkonfirmasi kepada calon mempelai laki-laki dan calon mempelai wanita mengenai kesungguhan mereka untuk melanjutkan kehidupan baru rumah tangga. Setelah kedua belah pihak keluarga yakin akan kesungguhan kedua calon mempelai maka dilanjutkan ke prosesi selanjutnya sesuai dengan penentuan hari baik atau ada juga yang langsung menjemput calon mempelai wanita.

3. Upacara Pawiwahan atau prosesi utama dilakukan pada hari yang telah disepakati dan dimulai 
pagi hari sekitar jam jam 04:00/06:00. Pada tahapan ini calon mempelai wanita dijemput oleh calon mempelai laki-laki. Sesampai di rumah calon mempelai laki-laki dilakukan upacara Pekala-kalaan/Metanjung untuk sambuk atau pengesahan perkawinan secara niskala yang dipimpin oleh seorang Pemangku.

4. Mejejauman/Tipat Bantal, biasanya dilakukan tidak lama setelah hari prosesi upacara Pawiwahan atau pada hari itu juga setelah prosesi Pawiwahan. Pada tahapan ini dilakukan upacara Pawidi widana yaitu pengesahan perkawinan secara lengkap dan biasanya dipuput oleh sang sulinggih/Ida Peranda. Acara dilanjutkan dengan prosesi membawa upacara Jejauman/tipat Bantal dari keluarga laki-laki kepada keluarga perempuan. Prosesi ini bermakna bahwa antara mempelai laki dan mempelai perempuan telah disatukan secara sekala dan niskala. Biasanya pada prosesi ini disini dihadiri oleh para pamucuk/pemimpin seperti Bendesa, Kelian adat, dan Pemangku dari kedua pihak untuk menyelesaikan prosesi pernikahan secara administratif dan upakara/banten sebagai sarana matur piuning, dimana saat itu mempelai wanita sah diambil dan meninggalkan rumahnya. Symbol tipat melambangkan perempuan dan bantal melambangkan laki laki, disinilah akan bersatu. Setelah prosesi ini kedua mempelai telah sah secara sekala niskala dan telah mendapat pengakuan hak dan kewajiban yg sama sebagaimana hak dan kewajiban krama banjar lainnya.

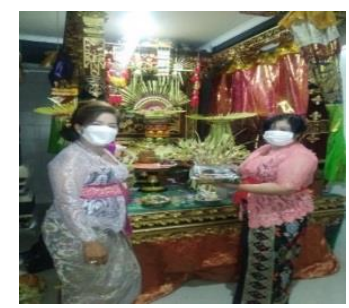

Gambar 2. Prosesi Ngabe Tipat Bantal

Setiap tahapan ini dilaksanakan dengan baik oleh karena terdapat symbol atau pesan yang ingin disampaikan dan harus diketahui oleh kedua mempelai, sehingga ketika setelah berumah tangga mereka siap dengan kehidupannya yang baru. Penelitian ini dilakukan dengan menggunakan kajian ekolinguistik, yang lebih yang lebih menitikberatkan pada hubungan lingkungan dalam wujud kebahasaan. Sedangkan penelitian yang diajukan lebih melihat bagaimana keberadaan makanan tradisional dan mengetahui fungsi dan makna makanan tradisional dalam suatu upacara adat Pawiwahan.

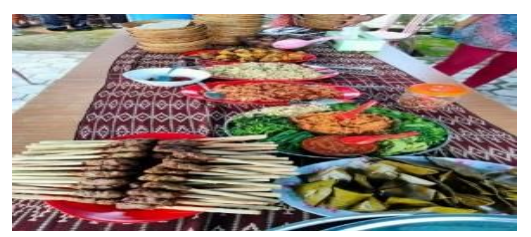

Gambar 3. Jamuan makanan pada upacara Pawiwahan Banjar Pelambingan 
Dari hasil pengamatan diperoleh banyak variasi makanan tradisional khas Bali dan makanan hasil kulturisasi dengan budaya lain seperti capcay, bihun goreng, pelecing kangkung dan banyak lagi. Berdasarkan budaya bali khususnya masyarakat desa Tibubeneng hanya 8 jenis makanan yang wajib di sajikan pada upacara Pawiwahan. Berdasarkan hasil wawancara dengan Bendesa adat, pemangku dan klian diperoleh data bahwa 8 jenis makanan yang wajib hadir pada upacara adat Pawiwahan adalah Sambal mbe, Sate, Lawar, Tum, Urutan Daging, Betutu, Jukut ares dan Urap. Dalam implementasinya indeksikalitas makanan tradisional tersebut hadir sebagai konsep yang hidup dalam sistem sosial budaya dan erat kaitannya dengan pengertian makanan. Fungsi makanan berlaku dalam masyarakat sebagai salah satu unsur kebudayaan, diyakini kebenarannya melalui ibadahnya dan memberikan dorongan untuk dapat memenuhinya. Bagi masyarakat Bali makanan yang wajib hadir atau di suguhkan dalam acara adat pawiwahan karena sesuai dengan adat dan budaya Bali, karena erat dengan makanan suci atau sukla yang di gunakan pada sesajen atau katur leluhur pada upacara keagamaan yang merupakan warisan budaya Bali. Berdasarkan hasil penelitian 8 jenis makanan yang wajib disajikan diperoleh data alat, bahan, bumbu dan proses pembuatan makanan.

\section{Sambel $M b e$}

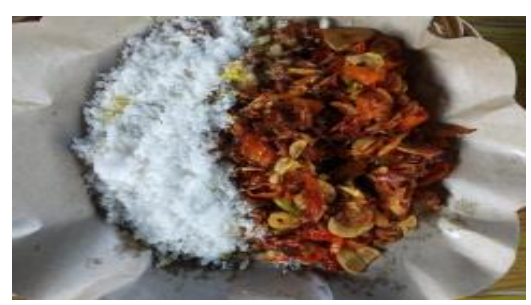

Gambar 5. Uyah Sambel Mbe

Berdasarkan peta konsep makanan tradisional Bali, sambal termasuk kedalam ragam pelengkap makanan tradisional. Sambal dibagi menjadi 2 yaitu sambal yang dimasak dan sambal yang tidak di masak. Sambal embe termasuk kedalam sambal yang dimasak dengan menggunakan sedikit minyak. Embe dalam bahasa Bali adalah bawang merah yang digoreng. 
Tabel 1. Indeksikalitas Makanan Sambal Embe

\begin{tabular}{|c|c|c|c|c|c|}
\hline \multirow{2}{*}{$\begin{array}{c}\text { Jenis } \\
\text { Makanan }\end{array}$} & \multicolumn{5}{|c|}{ Leksikon } \\
\hline & Alat dan Bahan & Glos & Aktivitas & Glos & Fungsi \\
\hline \multirow{13}{*}{$\begin{array}{l}\text { Sambal } \\
\text { embe }\end{array}$} & Alat & & & & \multirow{13}{*}{$\begin{array}{l}\text { Sambal embe } \\
\text { termasuk makanan } \\
\text { yang wajib ada dalam } \\
\text { pawiwahan. Embe } \\
\text { termasuk makanan } \\
\text { sukla Nasi pradnyan } \\
\text { yang digunakan pada } \\
\text { sajen Saraswati }\end{array}$} \\
\hline & Tiuk/Pisau & Pisau dapur & & & \\
\hline & Tungku & Kompor & & & \\
\hline & Talenan & $\begin{array}{l}\text { Landasan kayu } \\
\text { tempat } \\
\text { memotong }\end{array}$ & & & \\
\hline & Kate-kate & Penggorengan & & & \\
\hline & \multicolumn{4}{|l|}{ Bahan } & \\
\hline & Bawang & $\begin{array}{l}\text { Bawang } \\
\text { Merah }\end{array}$ & Ngumbah & Mencuci & \\
\hline & Tabia & Cabe kecil & Nektek & Mencincang & \\
\hline & Sera & Terasi & Melut & Mengupas & \\
\hline & Minyak tandusan & $\begin{array}{l}\text { Minyak } \\
\text { goreng }\end{array}$ & Numis & Menumis & \\
\hline & Uyah & Garam & Meres & Memeras & \\
\hline & Gula & & & & \\
\hline & Limo & Jeruk limau & & & \\
\hline
\end{tabular}

\section{Sate}

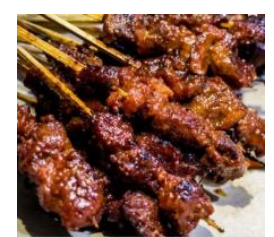

Gambar 6. Sate babi

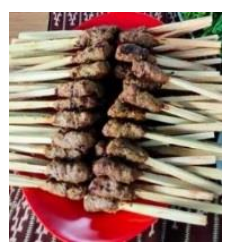

Gambar 7. Sate lilit babi

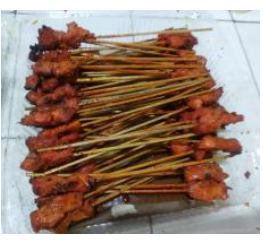

Gambar 8. Sate ayam

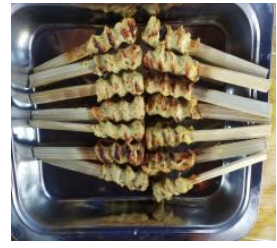

Gambar 9. Sate lilit ayam

Sate [sate] 'sate' adalah salah satu makanan tradisional khas Bali yang termasuk dalam lauk pokok dalam suatu acara jamuan. Berdasarkan pengolahannya sate dibedakan menjadi 2 macam yaitu a)sate yang bahannya dipotong dan diberi bumbu, b)sate yang bahannya di haluskan/dicincang bersama bumbu, kemudian di kepal-kepal pada bilah bambu atau batang daun sere, sate ini juga disebut sate lilit [lilit]. Variasi sate banyak ditemukan dalam upacara pawiwahan adalah sate babi, sate ayam, sate lilit babi dan sate lilit ayam. Dalam lontar Dharma Caruban yang digunakan sebagai tutunan masyarakat Hindu dalam membuat sajen/bebanten, dijelaskan bahwa sate digunakan sebagai upakara Galungan dan Kuningan sebagai simbol senjata Sang Hyang Nawa Dewata. Berikut adalah berbagai jenis sate yang digunakan dalam upacara adat Pawiwahan. Sate lilit pada acara pawiwahan merupakan simbol tanda pemersatu dua karakter pasangan pengantin. Makna lain dari sate lilit adalah simbol kejantanan seorang lelaki. Pada mulanya, sate lilit hanya boleh dimasak atau dikerjakan oleh kaum lelaki, karena proses pembakaran sate lilit dibakar dengan cara dijadikan satu pada batang pelepah pisang besar. Puluhan batang sate lilit tersebut ditusukkan pada batang pelepah pisang lalu dibakar di atas bara api. Proses ini membutuhkan tenaga ekstra untuk mengangkatnya yang hanya bisa 
dilakukan oleh kaum lelaki. Jadi bisa dikatakan bila lelaki belum pernah membuat sate lilit, belum disebut sebagai lelaki.

Tabel 2. Indeksikalitas Makanan Sate

\begin{tabular}{|c|c|c|c|c|c|}
\hline \multirow{2}{*}{$\begin{array}{c}\text { Jenis } \\
\text { Makanan }\end{array}$} & \multicolumn{5}{|c|}{ Leksikon } \\
\hline & $\begin{array}{c}\text { Alat dan } \\
\text { Bahan }\end{array}$ & Glos & Aktivitas & Glos & Fungsi \\
\hline \multirow{13}{*}{$\begin{array}{c}\text { Sate Babi } \\
\text { dan Sate } \\
\text { Ayam }\end{array}$} & \multicolumn{4}{|l|}{ Alat } & \multirow{13}{*}{$\begin{array}{lr}\text { Sate ayam atau babi } \\
\text { wajib disajikan } \\
\text { dalam } & \text { upacara } \\
\text { Pawiwahan karena } \\
\text { merupakan makanan } \\
\text { suklar yang } \\
\text { digunakan dalam } \\
\text { upakara galungan } \\
\text { dan kuningan. }\end{array}$} \\
\hline & Tiuk/Pisau & Pisau dapur & & & \\
\hline & Talenan & $\begin{array}{l}\text { Landasan kayu } \\
\text { tempat memotong }\end{array}$ & & & \\
\hline & Katik & Bilah bambu & & & \\
\hline & $\begin{array}{l}\text { Arang kayu / } \\
\text { batok kelapa }\end{array}$ & & & & \\
\hline & \multicolumn{4}{|c|}{ Bahan Utama Daging Babi atau Ayam } & \\
\hline & Kesuna & Bawang Putih & Ngumbah & Mencuci & \\
\hline & Tabia & Cabe kecil & Gulig & $\begin{array}{l}\text { Menghaluskan } \\
\text { bumbu }\end{array}$ & \\
\hline & Sera & Terasi & Melut & Mengupas & \\
\hline & Mica & Merica & Meres & Memeras & \\
\hline & Uyah & Garam & Мetunu & $\begin{array}{l}\text { Membakar } \\
\text { diatas bara }\end{array}$ & \\
\hline & Lombok & Cabe besar & Ngetep & $\begin{array}{l}\text { Memotong } \\
\text { daging }\end{array}$ & \\
\hline & Kunyit & Kunyit & & & \\
\hline \multirow{14}{*}{$\begin{array}{c}\text { Sate lilit } \\
\text { babi atau } \\
\text { ayam }\end{array}$} & \multicolumn{4}{|l|}{ Alat } & \multirow{14}{*}{$\begin{array}{l}\text { Sate lilit merupakan } \\
\text { bentuk } \\
\text { penghormatan } \\
\text { kepada para dewa. } \\
\text { Selain itu } \\
\text { berdasarkan budaya } \\
\text { masyarakat Bali sate } \\
\text { lilit } \\
\text { merepresentasikan } \\
\text { laki-laki sebagai } \\
\text { purusa atau generasi } \\
\text { penerus. }\end{array}$} \\
\hline & Tiuk/Pisau & Pisau dapur & & & \\
\hline & Talenan & $\begin{array}{l}\text { Landasan kayu } \\
\text { tempat memotong }\end{array}$ & & & \\
\hline & Katik & Bilah bamboo & & & \\
\hline & $\begin{array}{l}\text { Arang } \\
\text { kayu/batok } \\
\text { kelapa }\end{array}$ & & & & \\
\hline & \multicolumn{4}{|c|}{ Bahan Daging Babi atau ayam } & \\
\hline & Kesuna & Bawang Putih & Ngumbah & Mencuci & \\
\hline & Tabia & Cabe kecil & Gulig & $\begin{array}{l}\text { Menghaluskan } \\
\text { bumbu }\end{array}$ & \\
\hline & Lombok & Cabe besar & Melut & Mengupas & \\
\hline & Sera & Terasi & Meres & Memeras & \\
\hline & Mica & Merica & Metunu & $\begin{array}{l}\text { Membakar } \\
\text { diatas bara }\end{array}$ & \\
\hline & Uyah & Garam & Nektek & Mencincang & \\
\hline & Kunyit & & & & \\
\hline & Nyuh & Kelapa & & & \\
\hline
\end{tabular}

3. Lawar

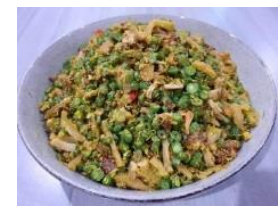

Gambar 10. Lawar Kacang Babi

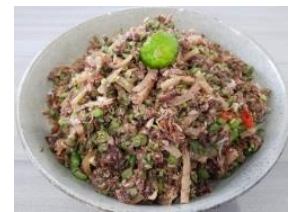

Gambar 11. Lawar Kulit Babi

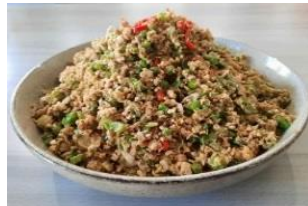

Gambar 12. Lawar Nangka Babi

Online at https://journal.universitasbumigora.ac.id/index.php/humanitatis/

DOI : https://doi.org/10.30812/humanitatis.v8i1.1465 
Lawar adalah makanan khas Bali yang terdiri dari sayuran dan daging (ayam/babi/bebek), serta diberi darah dari babi. Berdasarkan sejarah dan budaya Bali tradisi ngelawar berkembang sejak jaman kerajaan Bali berjaya, karena Raja Bali senang menikmati masakan lawar. Berbagai campuran bumbu pada lawar yang digunakan pada upacara pawiwahan mengandung pesan, perbedaan dua karakter bukanlah penghalang untuk hidup rukun dan harmonis. Proses memasak lawar tidak menggunakan api namun bahan yang digunakan harus dalam keadaan sudah di masak dengan cara di kukus. Untuk darah mentah Babi yang digunakan di matangkan dengan mengunakan air perasan jeruk limo. Bumbu yang digunakan pada masakan lawar adalah base genep dan dicampur dengan parutan kelapa теtunu.

Tabel 3. Indeksikalitas Makanan Lawar

\begin{tabular}{|c|c|c|c|c|c|}
\hline \multirow{2}{*}{$\begin{array}{c}\text { Jenis } \\
\text { Makanan }\end{array}$} & \multicolumn{5}{|c|}{ Leksikon } \\
\hline & $\begin{array}{c}\text { Alat dan } \\
\text { Bahan }\end{array}$ & Glos & Aktivitas & Glos & Fungsi \\
\hline \multirow{22}{*}{ Lawar } & Alat & & & & \multirow{22}{*}{$\begin{array}{l}\text { Lawar } \\
\text { wajib } \\
\text { digunakan } \\
\text { dalam } \\
\text { setiap acara } \\
\text { keagamaan. } \\
\text { Simbol } \\
\text { lawar } \\
\text { adalah } \\
\text { sebagai } \\
\text { bentuk rasa } \\
\text { syukur atas } \\
\text { berkah } \\
\text { yang } \\
\text { diberikan } \\
\text { oleh Tuhan. }\end{array}$} \\
\hline & Tiuk/Pisau & Pisau dapur & & & \\
\hline & Talenan & $\begin{array}{l}\text { Landasan kayu } \\
\text { tempat } \\
\text { memotong }\end{array}$ & & & \\
\hline & Wadah & & & & \\
\hline & kekeb & Dangdang & & & \\
\hline & \multicolumn{4}{|l|}{ Bumbu Utama } & \\
\hline & Kesuna & Bawang Putih & Ngumbah & Mencuci & \\
\hline & Bawang & Bawang Merah & Gulig & Menghaluskan bumbu & \\
\hline & Tabia & Cabe kecil & Melut & Mengupas & \\
\hline & Sera & Terasi & Meres & Memeras & \\
\hline & Mica & Merica & Metunu & Membakar diatas bara & \\
\hline & Uyah & Garam & & & \\
\hline & Lombok & Cabe besar & & & \\
\hline & Cekuh & Kencur & & & \\
\hline & Limo & Jeruk Limau & & & \\
\hline & Nyuh & Kelapa & & & \\
\hline & Variasi Bahaı & ama & & & \\
\hline & Hati & Hati Babi & Nektek & Mencincang & \\
\hline & Sarab & Darah & Ngulet & $\begin{array}{ll}\text { Mencampur } & \text { semua } \\
\text { bahan dan bumbu } \\
\text { dengan tangan }\end{array}$ & \\
\hline & Jukut Kacang & Kacang Panjang & Mejek & $\begin{array}{l}\text { Meremas bahan dan } \\
\text { bumbu }\end{array}$ & \\
\hline & Rumbah & Irisan kulit babi & & & \\
\hline & Nangka & Nangka & & & \\
\hline
\end{tabular}

\section{Tum}
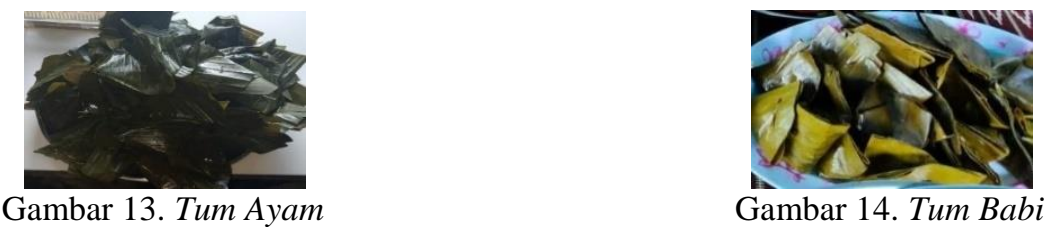

Pada upacara pawiwahan, tum disajikan sebagai lauk pauk pokok dan disajikan dalam 
beberapa variasi tum ayam, babi dan bebek. Tum adalah masakan tradional bali yang menggunakan bahan dasar daging, dan proses memasaknya di kekeb/kukus dengan menggunakan bumbu base genep. Tum daging (babi) bisanya dicampur dengan darah segar seperti lawar barak namun kemudian di bungkus rapat oleh daun pisang. Proses membungkus semua bahan ke dalam daun pisang memiliki makna sebagai representasi bagaimana sebagai pasangan pengantin ketika menghadapi setiap masalah yang dihadapi, harus disertai dengan instrospeksi masing-masing. Dilanjutkan dengan proses pengukusan tum hingga matang, aktivitas tersebut di maknai sebagai bentuk introspeksi menjadi tahapan untuk mencapai kedewasaan pasangan tersebut dalam mengarungi rumah tangga. Dalam kondisi seperti ini, masing-masing dituntut untuk tidak mencari kesalahan pasangannya. Namun, melakukan instropeksi di dalam diri terlebih dahulu dan perbaiki kesalahan yang sudah dilakukan.

Tabel 4. Indeksikalitas Makanan Tum

\begin{tabular}{|c|c|c|c|c|c|}
\hline \multirow{2}{*}{$\begin{array}{c}\text { Jenis } \\
\text { Makanan }\end{array}$} & \multicolumn{5}{|c|}{ Leksikon } \\
\hline & Alat dan Bahar & Glos & Aktivitas & Glos & Fungsi \\
\hline \multirow{25}{*}{ Tum } & & \multirow{25}{*}{$\begin{array}{lr}\text { Tum adalah } \\
\text { makanan wajib ada } \\
\text { pada } & \text { hari } \\
\text { penempahan } & \\
\text { Galungan } & \text { dan } \\
\text { kuningan. } & \\
\text { Tum adalah simbol } \\
\text { rasa syukur } \\
\text { berkah } & \text { atas } \\
\text { diberikan } & \text { yang } \\
\text { Tuhan. } & \end{array}$} \\
\hline & \multicolumn{4}{|l|}{$\begin{array}{l}\text { Alat } \\
\text { Tiuk/Pisau }\end{array}$} & \\
\hline & Talenan & $\begin{array}{l}\text { Landasan } \\
\text { kayu tempat } \\
\text { memotong }\end{array}$ & & & \\
\hline & Wadah & & & & \\
\hline & Kekep & Dandang & & & \\
\hline & \multicolumn{4}{|l|}{ Bumbu Utama } & \\
\hline & Kesuna & $\begin{array}{l}\text { Bawang } \\
\text { Putih }\end{array}$ & Ngumbah & Mencuci & \\
\hline & Bawang & $\begin{array}{l}\text { Bawang } \\
\text { Merah }\end{array}$ & Gulig & $\begin{array}{l}\text { Menghaluskan } \\
\text { bumbu }\end{array}$ & \\
\hline & Tabia & Cabe kecil & Melut & Mengupas & \\
\hline & Sera & Terasi & & & \\
\hline & \multirow{2}{*}{$\begin{array}{l}\text { Mica } \\
\text { Uyah }\end{array}$} & Merica & & & \\
\hline & & Garam & & & \\
\hline & Jae & Jahe & & & \\
\hline & Cekuh & Kencur & & & \\
\hline & Isen & Laos & & & \\
\hline & \multirow[t]{2}{*}{ Ketumbah } & Ketumbar & & & \\
\hline & & Jinten & & & \\
\hline & Jenugarum & $\begin{array}{l}\text { Pala } \\
\end{array}$ & & & \\
\hline & \multirow{2}{*}{\multicolumn{4}{|c|}{\begin{tabular}{l|l} 
Don jangan ulam & Daun Salam \\
Variasi Bahan Utama \\
\end{tabular}}} & \\
\hline & & & & & \\
\hline & \multicolumn{2}{|c|}{\begin{tabular}{|l|l|} 
Daging & Daging Babi \\
\end{tabular}} & Ngukus & Mengukus & \\
\hline & Besiap & Ayam & Ngulet & $\begin{array}{l}\text { Mencampur } \\
\text { semua bahan dan } \\
\text { bumbu dengan } \\
\text { tangan }\end{array}$ & \\
\hline & Jukut Kacang & Kacang Panjang & Mejek & $\begin{array}{l}\text { Meremas bahan } \\
\text { dan bumbu }\end{array}$ & \\
\hline & Rumbah & Irisan kulit babi & & & \\
\hline & Nangka & Nangka & & & \\
\hline
\end{tabular}




\section{Jukut}

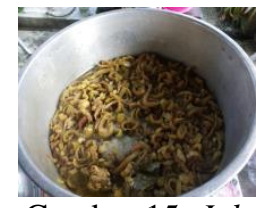

Gambar 15. Jukut Ares

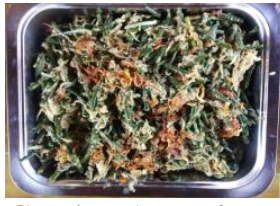

Gambar 16. Jukut Kacang

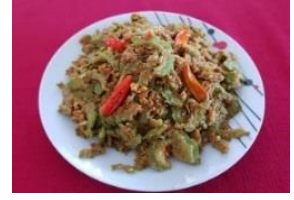

Gambar 17. Jukut Paye

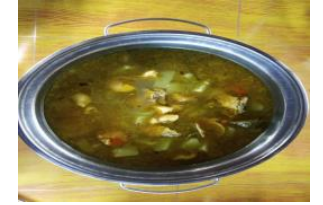

Gambar 18. Jukut Kuah Ayam

Berdasarkan kamus bahasa Bali 'Jukut' [jukvt] adalah daun-daunan(sawi), tumbuhtumbuhan(taoge), polonga tau biji-bijian (kapri, buncis) yang dapat dimasak atau bisa juga diartikan sebagai masakan yang berkuah dengan campuran dedaunan yang dapat dimakan(Partami, Sudiana, Sukayan, \& Ida Ayu Mirah Purwiati, 2016). Masyarakat di pulau Bali banyak mengkonsumsi sayuran, karena pulau Bali diberikan daerah yang subur dan beriklim tropis. Kelimpahan sumber daya alam ini dimanfaatkan oleh masyarakat untuk dalam menjalankan adat dan budaya ritual dalam kehidupan mereka. Jukut sebagai masakan tradisional yang menggunakan bahan utama sayuran dan memberikan campuran bahan hewani sebagai sumber protein. Masakan jukut ares selalu dihidangkan dalam setiap perayaan besar di masyarakat Bali seperti Pawiwahan, potong gigi, kematian atau hari raya Galungan(Labib, 2019). Masakan jukut dibagi menjadi 2 macam yaitu jukut tidak berkuah dan tidak berkuah.

a) Jukut tidak berkuah

Jukut tidak berkuah dibuat dari berbagai macam sayuran dan kacang-kacangan, seperti pelecing kangkung/kacang/gonde/telengis dengan bumbu base plecing atau bumbu base genep.

b) Jukut berkuah

Sedangkan jukut berkuah, biasanya terdiri dari sayuran dan kacang-kacangan dengan diberikan potongan hewani seperti ayam dan babi. Bumbu yang digunakan pada jukut berkuah adalah bumbu base genep. 
Tabel 5. Indeksikalitas Makanan Jukut

\begin{tabular}{|c|c|c|c|c|c|}
\hline \multirow{2}{*}{$\begin{array}{c}\text { Jenis } \\
\text { Makanan }\end{array}$} & \multicolumn{5}{|c|}{ Leksikon } \\
\hline & $\begin{array}{c}\text { Alat dan } \\
\text { Bahan }\end{array}$ & Glos & Aktivitas & Glos & Fungsi \\
\hline \multirow{21}{*}{$\begin{array}{l}\text { Jukut tidak } \\
\text { berkuah } \\
\text { (Ares/Kacang } \\
\text { /paye) }\end{array}$} & Alat & & & & \multirow{21}{*}{$\begin{array}{lr}\text { Jukut } & \text { adalah } \\
\text { makanan wajib ada } \\
\text { pada hari perayaan } \\
\text { besar } \\
\text { potong sepert } \\
\text { pawiwahan, } \\
\text { kematian } \\
\text { Galungan. } \\
\text { Jukut dan } \\
\text { simbol rasa syukur } \\
\text { atas berkah } \\
\text { kelimpahan alam } \\
\text { yang diberikan } \\
\text { oleh Tuhan. }\end{array}$} \\
\hline & Tiuk/Pisau & Pisau dapur & & & \\
\hline & Talenan & $\begin{array}{l}\text { Landasan kayu } \\
\text { tempat } \\
\text { memotong }\end{array}$ & & & \\
\hline & Wadah & & & & \\
\hline & $\begin{array}{l}\text { Batu } \\
\text { Panyatokan }\end{array}$ & Ulekan & & & \\
\hline & Kuali & Wajan & & & \\
\hline & \multicolumn{4}{|c|}{ Bumbu Utama } & \\
\hline & Cekuh & Kencur & Ngumbah & Mencuci & \\
\hline & Jae & Jahe & Gulig & $\begin{array}{l}\text { Menghaluskan } \\
\text { bumbu }\end{array}$ & \\
\hline & Isen & Laos & Melut & Mengupas & \\
\hline & Ketumbah & Ketumbar & Numis & Menumis & \\
\hline & & Jinten & Ngikih & Memarut & \\
\hline & Tabia & Cabe kecil & Meres & Memeras & \\
\hline & Sera & Terasi & & & \\
\hline & Lombok & Cabai besar & & & \\
\hline & Uyah & Garam & & & \\
\hline & Nyuh & Kelapa & & & \\
\hline & Variasi Bah & Utama & & & \\
\hline & Ares & $\begin{array}{l}\text { Batang Pohon } \\
\text { Pisang }\end{array}$ & Ngengseb & Merebus & \\
\hline & Kacang & Kacang Panjang & Ngulet & $\begin{array}{l}\text { Mencampur } \\
\text { semua bahan dan } \\
\text { bumbu dengan } \\
\text { tangan }\end{array}$ & \\
\hline & Paye & Ayam & Ngetep & $\begin{array}{lr}\text { Memotong } & \text { bahan } \\
\text { masakan dengan } \\
\text { ukuran } & \text { tidak } \\
\text { terlalu tipis } & \\
\end{array}$ & \\
\hline
\end{tabular}

\section{Urab}

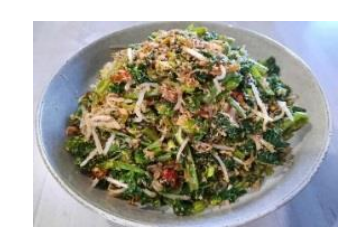

Gambar 19. Urab Bayam

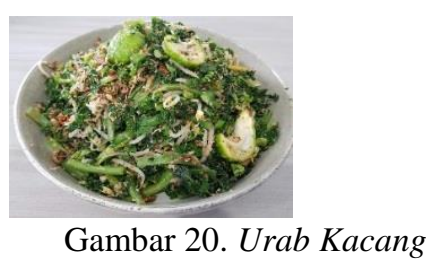

Gambar 20. Urab Kacang

Masakan tradisional urab [urab] masuk dalam klasifikasi jukut tidak berkuah, namun ada perbedaan pada penggunaan kelapa. Untuk masakan urab kelapa yang digunakan adalah kelapa yang diparut dan dicampur dengan semua bahan dan bumbu. Biasanya urab menggunakan berbagai sayuran seperti tauge, kangkung, kacang panjang, terung, gonde, daun ketela dan lain-lain. Berdasarkan lontar dharma caruban, urab termasuk makanan suci atau sukla karena merupakan makanan persembahan bagi Dewa Siwa dan Dewi Uma. Selain itu juga masakan tersebut di sajikan 
kepada pendeta atau pemangku ketika sedang memimpin suatu pada upacara adat(Widyawati \& Ambarnuari, 2020). Menurut salah satu tokoh adat, bahan-bahan dari masakan urab ini memiliki makna tertentu. Tauge berasal dari kacang hijau yang bermakna kesuburan, setelah menjadi kacang hijau berubah menjadi tauge bermakna pertumbuhan dan kreatifitas. Kangkung hidup di air dan di darat, makna dalam upacara pawiwahan adalah sebagai pasangan harus bisa beradaptasi dengan lingkungan baru dalam rumah tangganya. Kacang panjang bermakna bahwa hidup berpasangan selalu harus berpikir panjang dalam mengambil keputusan apapun.

Tabel 6. Indeksikalitas Makanan Urab

\begin{tabular}{|c|c|c|c|c|c|}
\hline \multirow{2}{*}{$\begin{array}{c}\text { Jenis } \\
\text { Makanan }\end{array}$} & \multicolumn{5}{|c|}{ Leksikon } \\
\hline & $\begin{array}{c}\begin{array}{c}\text { Alat dan } \\
\text { Bahan }\end{array} \\
\end{array}$ & Glos & Aktivitas & Glos & Fungsi \\
\hline \multirow{22}{*}{ Urab } & \multicolumn{4}{|l|}{ Alat } & \multirow{22}{*}{$\begin{array}{l}\text { Urab wajib } \\
\text { digunakan dalam } \\
\text { setiap acara } \\
\text { keagamaan } \\
\text { sebagai makanan } \\
\text { suci/sukla. Simbol } \\
\text { urab adalah } \\
\text { sebagai } \\
\text { persembahan } \\
\text { kepada Dewa } \\
\text { Siwa dan Dewi } \\
\text { Uma. }\end{array}$} \\
\hline & Tiuk/Pisau & Pisau dapur & & & \\
\hline & Talenan & $\begin{array}{l}\text { Landasan kayu } \\
\text { tempat memotong }\end{array}$ & & & \\
\hline & Wadah & & & & \\
\hline & Kikihan & Parutan & & & \\
\hline & \multicolumn{4}{|c|}{ Bumbu Utama } & \\
\hline & Kesuna & Bawang Putih & Ngumbah & Mencuci & \\
\hline & Bawang & Bawang Merah & Gulig & Menghaluskan bumbu & \\
\hline & Tabia & Cabe kecil & Melut & Mengupas & \\
\hline & Sera & Terasi & Meres & Memeras & \\
\hline & Mica & Merica & Metunu & Membakar diatas bara & \\
\hline & Uyah & Garam & Ngikih & Memarut & \\
\hline & Lombok & Cabe besar & & & \\
\hline & Cekuh & Kencur & & & \\
\hline & Limo & Jeruk Limau & & & \\
\hline & Nyuh & Kelapa & & & \\
\hline & Variasi Baha & tama & & & \\
\hline & Kacang & Kacang panjang & Nektek & Mencincang & \\
\hline & Don bayam & Bayam & Ngulet & $\begin{array}{l}\text { Mencampur semua } \\
\text { bahan dan bumbu } \\
\text { dengan tangan }\end{array}$ & \\
\hline & Togé & Taoge & Mejek & $\begin{array}{l}\text { Meremas bahan dan } \\
\text { bumbu }\end{array}$ & \\
\hline & Don gonde & Gonda & & & \\
\hline & Don séla & Daun ketela & & & \\
\hline
\end{tabular}

\section{Be'urutan}

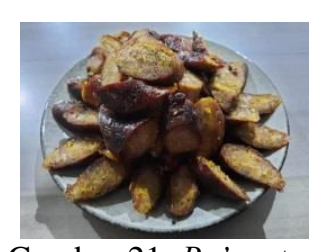

Gambar 21. Be'urutan

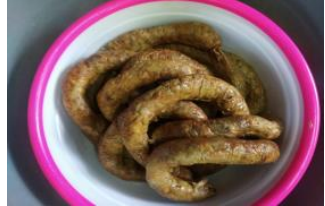

Gambar 22. Be'urutan sebelum di potong

Be'urutan berasal dari kata bé (lauk) dan urutan (lauk yang terbuat dari usus yang berisi daging yang di potong kecil-kecil, diisi bumbu lalu di goreng(Partami et al., 2016). Urutan adalah adalah masakan tradisional Bali yang dibuat dari usus babi dan diisi oleh daging babi cincang beserta lemaknya lalu dicampur dengan bumbu basa genep dan dibentuk seperti sosis. Makanan ini termasuk 
makanan yang dapat disimpan dalam waktu yang lama melalui proses pengeringan dengan cara di jemur dibawah sinar matahari. Sebelum disajikan urutan harus di goreng terlebih dahulu.

Tabel 7. Indeksikalitas Makanan Be'urutan

\begin{tabular}{|c|c|c|c|c|c|}
\hline \multirow{2}{*}{$\begin{array}{c}\text { Jenis } \\
\text { Makanan }\end{array}$} & \multicolumn{5}{|c|}{ Leksikon } \\
\hline & $\begin{array}{c}\text { Alat dan } \\
\text { Bahan }\end{array}$ & Glos & Aktivitas & Glos & Fungsi \\
\hline \multirow{20}{*}{ Be'urutan } & Alat & & & & \multirow{20}{*}{$\begin{array}{l}\text { Be'urutan wajib } \\
\text { disajikan dalam } \\
\text { upacara Pawiwahan } \\
\text { karena merupakan } \\
\text { makanan sukla yang } \\
\text { digunakan sebagai } \\
\text { makanan } \\
\text { persembahan dalam } \\
\text { upacara adat. }\end{array}$} \\
\hline & Tiuk/Pisau & Pisau dapur & & & \\
\hline & Talenan & $\begin{array}{l}\text { Landasan kayu } \\
\text { tempat memotong }\end{array}$ & & & \\
\hline & Kuali & Wajan & & & \\
\hline & Wadah & & & & \\
\hline & \multicolumn{4}{|c|}{ Bahan Utama dan Bumbu } & \\
\hline & Ulam bawi & Daging babi & Ngumbah & Mencuci & \\
\hline & Bawi & Usus babi & Nektek & Mencincang & \\
\hline & Muluk bawi & Lemak babi & Mejek & $\begin{array}{lr}\text { Meremas } & \text { bahan } \\
\text { makanan } & \text { dengan } \\
\text { bumbu }\end{array}$ & \\
\hline & Kesuna & Bawang putih & Ngulet & Mengaduk Bahan & \\
\hline & Bawang & Bawang & Nggoreng & Menggoreng & \\
\hline & Ketumbah & Ketumbar & Gulig & $\begin{array}{l}\text { Menghaluskan } \\
\text { bumbu }\end{array}$ & \\
\hline & Jinten & Jinten & Melut & Mengupas & \\
\hline & Cekuh & Kencur & & & \\
\hline & Sera & Terasi & & & \\
\hline & Mica & Merica & & & \\
\hline & Kunyit & Kunyit & & & \\
\hline & Jae & Jahe & & & \\
\hline & Isen & Laos & & & \\
\hline & Uyah & Garam & & & \\
\hline
\end{tabular}

\section{Betutu}

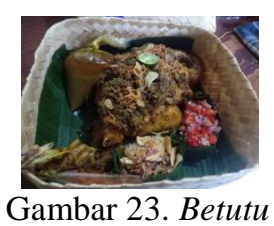

Ayam betutu adalah salah satu makanan tradisional khas Bali yang sangat popular dan memiliki citarasa yang unik berasal dari berbagai bumbu dan rempah. 'Betutu' be[th]u[th]u/ adalah proses pengolahan yang menggunakan ayam atau bebek dalam bentuk utuh dan kemudian direbus/ungkep hingga air dan bumbunya mengering, biasanya dibutuhkan waktu lebih dari 1 jam untuk mendapatkan daging ayam/bebek betutu yang lunak dan sebelum disajikan betutu tersebut dibakar untuk memperkuat citarasa. Makanan ini wajib ada dalam setiap kegiatan adat, keagamaan ataupun perayaan-perayaan besar. Jenis makanan ini awalnya dikenal hanya di daerah Gianyar, namun saat ini hampir semua orang tidak hanya etnis Bali yang beragama Hindu tapi hampir semua etnis yang pernah tinggal atau berkunjung di Bali pernah merasakan masakan tradisional ini(Purna \& 
Dwikayana, 2019). Namun saat ini para penikmat kuliner tradisional Bali Betutu, lebih mengenal betutu sebagai makanan ciri khas daerah Gilimanuk.(Pratama \& Umiyati, 2021). Dalam pelaksanaan upacara keagamaan ataupun adat, betutu digunakan sebagai banten dalam upacara manusia yadnya, seperti upacara pagedong-gedongan, otonan, metatah, pawiwahan sampai kepada upacara ngaben. Jenis betutu yang digunakan dalam pelaksanaan upacara tersebut adalah bebek betutu. Bebek/kuwir dipilih untuk digunakan dalam upacara adat karena termasuk binatang yang suci sebagai persembahan kepada Ida Sang Hyang Widhi Wasa, para dewa-dewi maupun Ida Bhatara-Bhatari(Suadnyana, 2018).

Tabel 8. Indeksikalitas Makanan Betutu

\begin{tabular}{|c|c|c|c|c|c|}
\hline \multirow{2}{*}{$\begin{array}{c}\text { Jenis } \\
\text { Makanan }\end{array}$} & \multicolumn{5}{|c|}{ Leksikon } \\
\hline & Alat dan Bahan & Glos & Aktivitas & Glos & Fungsi \\
\hline \multirow{25}{*}{$\begin{array}{c}\text { Betutu } \\
\text { (Ayam/Be } \\
\text { bebek) }\end{array}$} & \multicolumn{4}{|l|}{ Alat } & \multirow{25}{*}{ 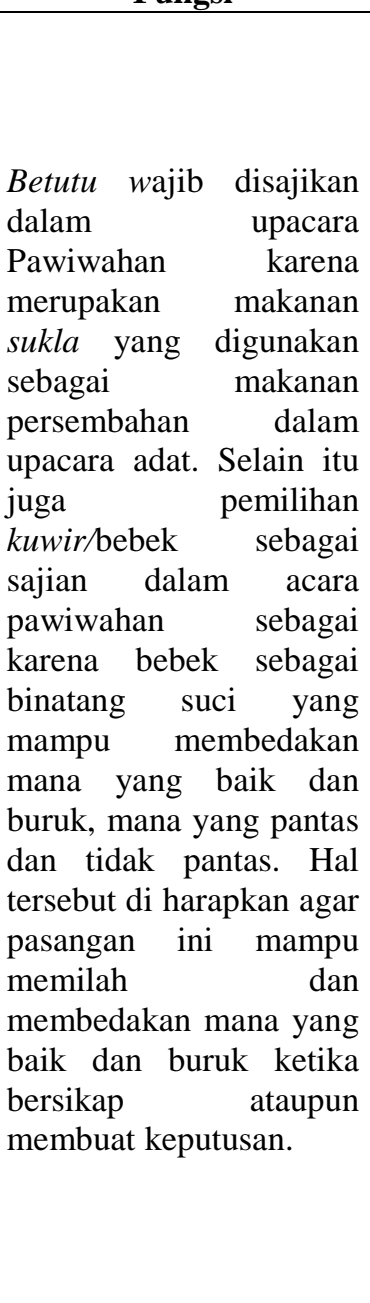 } \\
\hline & Tiuk/Pisau & Pisau dapur & & & \\
\hline & Talenan & $\begin{array}{l}\text { Landasan } \\
\text { kayu tempat } \\
\text { memotong }\end{array}$ & & & \\
\hline & Kuali & Wajan & & & \\
\hline & Payuk & Periuk & & & \\
\hline & Batu Penyatokan & Ulekan & & & \\
\hline & $\begin{array}{l}\text { Arang kayu atau } \\
\text { batok kelapa }\end{array}$ & & & & \\
\hline & \multicolumn{4}{|c|}{ Bahan Utama dan Bumbu } & \\
\hline & Besiap & Ayam & Ngumbah & Mencuci & \\
\hline & Kuwir & Bebek & Melut & Mengupas & \\
\hline & Kesuna & Bawang putih & Gulig & $\begin{array}{l}\text { Menghaluska } \\
\text { n bumbu }\end{array}$ & \\
\hline & Bawang & Bawang & Numis & $\begin{array}{l}\text { Menumis } \\
\text { bumbu }\end{array}$ & \\
\hline & Tingkih & Kemiri & Nyakcak & Mememarkan & \\
\hline & Tabia & Cabai kecil & Melablab & Merebus & \\
\hline & Cekuh & Kencur & Metunu & Memanggang & \\
\hline & Mica & Merica & & & \\
\hline & Kunyit & Kunyit & & & \\
\hline & Jae & Jahe & & & \\
\hline & Isen & Laos & & & \\
\hline & Jebugarum & Pala & & & \\
\hline & Uyah & Garam & & & \\
\hline & Don sumagané & Daun Jeruk & & & \\
\hline & $\begin{array}{l}\text { Don jangan } \\
\text { ulam }\end{array}$ & Daun Salam & & & \\
\hline & Don biu & Daun Pisang & & & \\
\hline & Seré & Sereh & & & \\
\hline
\end{tabular}

\section{Kesimpulan}

Online at https://journal.universitasbumigora.ac.id/index.php/humanitatis/

DOI $\quad$ : https://doi.org/10.30812/humanitatis.v8i1.1465 
Setiap masakan yang yang wajib disajikan sebagai makanan pokok utama dalam upacara Pawiwahan memiliki makna dan dipercayai sebagai pengharapan/doa bagi pasangan pengantin kerika memasuki kehidupan rumah tangga. Makanan tersebut juga dikategorikan sebagai makanan sukla/suci, dikarenakan dijadikan bahan persembahan/banten dalam upacara keagamaan ataupun adat istiadat masyarakat etnis Bali. Jenis makanan yang wajib ada dalam acara pawiwahan ada 8 jenis yaitu : Sambal embe, sate, lawar, Jukut, tum, urab, be'urutan, betutu. Seiring dengan laju pertumbuhan penduduk di Desa Tibubeneng, banyak pendatang dari berbagai etnis dan agama yang menetap di desa Tibubeneng, mempengaruhi budaya kuliner asli masyarakat desa Tibubeneng. Makanan yang disajikan dalam upacara Pawiwahan mulai dipengaruhi dengan masakan-masakan modern, namun kuatnya penerapan awig-awig oleh masyarakat sekitar mampu mempertahankan indeksikalitas makanan tradisional yang wajib ada dalam upacara Pawiwahan. Dalam implementasinya indeksikalitas makanan tradisional tersebut hadi sebagai konsep yang hidup dalam sistem sosial budaya dan erat kaitannya dengan pengertian makanan, fungsi makanan dan berlaku dalam masyarakat sebagai salah satu unsure kebudayaan, diyakini kebenarannya melalui ibadahnya dan memberikan dorongan untuk dapat memenuhinya.

\section{REFERENCES}

Kartika, Y. (2020). Pernikahan Adat Jawa Pada Masyarakat Islam di Desa Kalidadi Kecamatan Kalirejo Kabupaten Lampung Tengah.

Labib, M. A. (2019). Sajian desa adat payangan, bali. Sekolah Tinggi Pariwisata Bandung.

Ningsih, L. S., \& Suwendra, I. W. (2020). Upacara Pawiwahan dalam Agama Hindu. Jurnal Widya Sastra Pendidikan Agama Hindu, 3(2), 40-49. Retrieved from https://jurnal.stkipahsingaraja.ac.id/index.php/wspah/article/view/74

Partami, N. L., Sudiana, I. M., Sukayan, I. N., \& Ida Ayu Mirah Purwiati. (2016). KAMUS BAHASA BALI- INDONESIA Edisi Ke-3. BALAI BAHASA BALI.

Pawana, I. G. (2018). Prosesi Upacara Perkawinan Adat Bali Di Desa Duda Timur. Jurnal Pangkaja, 21(2).

Pratama, A. D. Y., \& Umiyati, M. (2021). The Knowledge Level of Housewives about Serving Ayam Betutu. RETORIKA: Jurnal Ilmu Bahasa, 7(1), 58-68.

Purna, I. M., \& Dwikayana, K. (2019). Betutu Bali : Menuju Kuliner Diplomasi Budaya Indonesia Betutu of Bali : Patanjala, 9(2), 265-280. https://doi.org/10.30959/patanjala.v11i2.478

Suadnyana, I. B. P. E. (2018). Sang Hyang Sambah Dalam Ngusabha Sambah di Desapakraman Pesedahan, Manggis, Karangasem. Jurnal Sanjiwani, 9(1), 87-96.

Taya, N. I., Rumampuk, S., \& Sandiah, N. (2021). Adat Perkawinan Suku Bangsa Tobelo Di Desa Loleba Kecamatan Wasile Selatan Kabupaten Halmahera Timur. Jurnal Holistik, 14(2), 1-13.

Tyas, A. S. P. (2017). Identifikasi Kuliner Lokal Indonesia dalam Pembelajaran Bahasa Inggris.

Online at https://journal.universitasbumigora.ac.id/index.php/humanitatis/

DOI : https://doi.org/10.30812/humanitatis.v8i1.1465 
Jurnal Pariwisata Terapan, 1(2), 38. https://doi.org/10.22146/jpt.24970

Widyawati, A. A. A. A., \& Ambarnuari, M. (2020). Upacara Menek Deha. Jurnal Pangkaja, 23(2), 28-41. Retrieved from http://ejournal.ihdn.ac.id/index.php/PJAH/article/view/2075/1563 
Online at https://journal.universitasbumigora.ac.id/index.php/humanitatis/ DOI : https://doi.org/10.30812/humanitatis.v8i1.1465 